\title{
Aspects of the ecology of killer whale (Orcinus orca Linn.) groups in the near- shore waters of Sub-Antarctic Macquarie Island
}

Travers, Toby ${ }^{1}$, van den Hoff, John ${ }^{2 *}$, Lea, Mary-Anne ${ }^{1,3}$, Carlyon, Kris ${ }^{4}$, Reisinger, Ryan ${ }^{5,6}$, de Bruyn, P.J. Nico ${ }^{7}$, Morrice, Margie ${ }^{8}$

${ }^{1}$ Institute for Marine and Antarctic Studies, University of Tasmania, 20 Castray Esplanade, Hobart, Tasmania 7000, Australia.

${ }^{2}$ Australian Antarctic Division, 203 Channel Highway, Kingston, Tasmania 7050, Australia.

${ }^{3}$ Antarctic Climate and Ecosystems CRC, 20 Castray Esplanade, Hobart, Tasmania 7000, Australia.

${ }^{4}$ Marine Conservation Program, Department of Primary Industries, Parks, Water and Environment, 134 Macquarie Street, Hobart, Tasmania 7000, Australia.

${ }^{5}$ Department of Zoology, Nelson Mandela University, P.O. Box 77000, Port Elizabeth, 6031, South Africa.

${ }^{6}$ Centre d'Etudes Biologique de Chizé, UMR 7372 du Centre National de la Recherche Scientifique-Université de La Rochelle, 79360 Villiers en Bois, France.

${ }^{7}$ Mammal Research Institute, Department of Zoology and Entomology, University of Pretoria, Private Bag X20, Hatfield 0028, South Africa.

${ }^{8}$ School of Life and Environmental Sciences, Deakin University, PO Box 432, Warrnambool, Victoria 3280, Australia.

* corresponding author: john_van@aad.gov.au

Additional keywords: diet, feeding behaviour, group size, southern elephant seal 


\section{Abstract}

Occurrences of killer whales (Orcinus orca) in the waters surrounding Sub-Antarctic Macquarie Island have been recorded since the 1820s, however only became the focus of scientific research in the mid-1990s. The analyses of sightings data collected from the island between 1986 and 2015 are presented herein. The study provides evidence of a relationship between killer whale sighting probability and seasonal prey availability. Killer whales were present at the island year-round with a distinct seasonal peak in November-December, and coincident with a peak in occurrence of southern elephant seals (Mirounga leonina) due to breeding season activity, particularly the dispersal of weaned pups. Supporting this association and killer whales' top-down influence on the survival of juvenile and adult southern elephant seals, pinnipeds accounted for $79 \%$ of prey identified, with weaned southern elephant seal pups contributing over a quarter of feeding events observed in the near-shore environment. Fur seals and penguins were also identified as prey. Killer whale groups had a median group size of three individuals, and groups of three to five individuals were most often observed feeding/milling in near-shore waters. The largest range in group sizes were observed during their peak occurrence in early summer, particularly in the number of sub-adult and female whales per group. Adult males made up $75 \%$ of single occurrences, and singletons were most often observed travelling. Overall, the ecology of killer whales at Macquarie Island was similar to that of killer whales studied at other Sub-Antarctic locations, with comparable seasonality, behaviour, diet, and group structure. Much remains to be learnt regarding the seasonal movements of whales and their diet at other times of year, their relationship to killer whales sighted in coastal Australian, New Zealand and Antarctic ecosystems, and impact on diet from commercial fisheries operations and fluctuating prey populations. 


\section{Introduction}

Lying roughly between the Antarctic Convergence and Subtropical Front, remote SubAntarctic islands and surrounding waters provide important habitat for far-ranging meso- and apex predators (Smith and Lewis-Smith 1987; Bergstrom and Chown 1999). The marine ecosystems around these islands are dynamic, and influenced by both short- and long-term environmental effects. Changes at the base of these ecosystems can create bottom-up pressures that shape the phenology, foraging success and abundances of predators, including killer whales (Orcinus orca) (Chambers et al. 2013; van den Hoff et al. 2014; Clausius et al. 2017).

The forces that shape the marine ecosystems surrounding Sub-Antarctic islands are a combination of both natural and anthropogenic effects, and these may influence the top-down regulatory role predators play in ecosystems. For example, hypotheses proposed to explain the decline in the southern elephant seal (Mirounga leonina) population at Macquarie Island (van den Hoff et al. 2007) included predation by killer whales, an apex predator, particularly if elephant seal numbers were low (McMahon et al. 2005). Growing fisheries pressures in the Southern Ocean have also influenced the distribution, abundance and prey selection of killer whales (Poncelet et al. 2010; Ainley and Ballard 2012; Guinet et al. 2015).

Relative to the Northern Hemisphere, little information exists for Southern Hemisphere (SH) killer whale populations. Within the SH, most Sub-Antarctic research has been conducted at the Crozet Islands and the Prince Edward Islands in the Indian Ocean sector with comparatively little corresponding work in the remainder of the region. Studies of SH killer whale populations describe great diversity in genetic identity, movement range, morphology, diet and behaviour whilst Sub-Antarctic studies show comparable group sizes and 
behaviours, diet, site fidelity and seasonal occurrences across study islands (de Bruyn et al. 2013). This study of killer whales in the waters surrounding Macquarie Island, an island in the West Pacific sector of the Sub-Antarctic, uses nearly three decades of data to investigate aspects of their ecology. We hypothesised that killer whales observed at Macquarie Island would have similar patterns of seasonality, behaviour, diet and group structure to populations studied at other Sub-Antarctic islands.

\section{Materials and Methods}

\section{Study area}

Field work was undertaken on Macquarie Island (Fig. 1). Surface water temperatures around the island range from monthly mean winter lows of $2.8^{\circ} \mathrm{C}$ (July) to summer highs of $7.2^{\circ} \mathrm{C}$ (January) (Kenny and Haysom 1962). The nearest land lies over $600 \mathrm{~km}$ to the northeast at Campbell Island and winter sea-ice extends from the Antarctic coast to within $650 \mathrm{~km}$ south of the island. The island has a circumference of $c a .80 \mathrm{~km}$ with field huts spaced at intervals along the coastline, often adjacent to concentrations of breeding pinnipeds and penguins. Most human activity was associated with a research station located on the island's northern isthmus (Fig. 1).

Among the marine birds and mammals breeding on the island are large colonies of Royal Penguins (Eudyptes schlegeli) (ca. 850000 breeding pairs), King Penguins (Aptenodytes patagonicus) (ca. 150-170 000 breeding pairs), and southern elephant seals (ca. 20000 breeding females) (Fig. 1, http://www.parks.tas.gov.au, accessed 25/07/2017). A relatively small (ca. 350 breeding females, Dr. Rachael Alderman, DPIPWE, Tasmania) population of fur seals (Arctocephalus spp.), largely confined to north of the isthmus, also breeds on the island. 


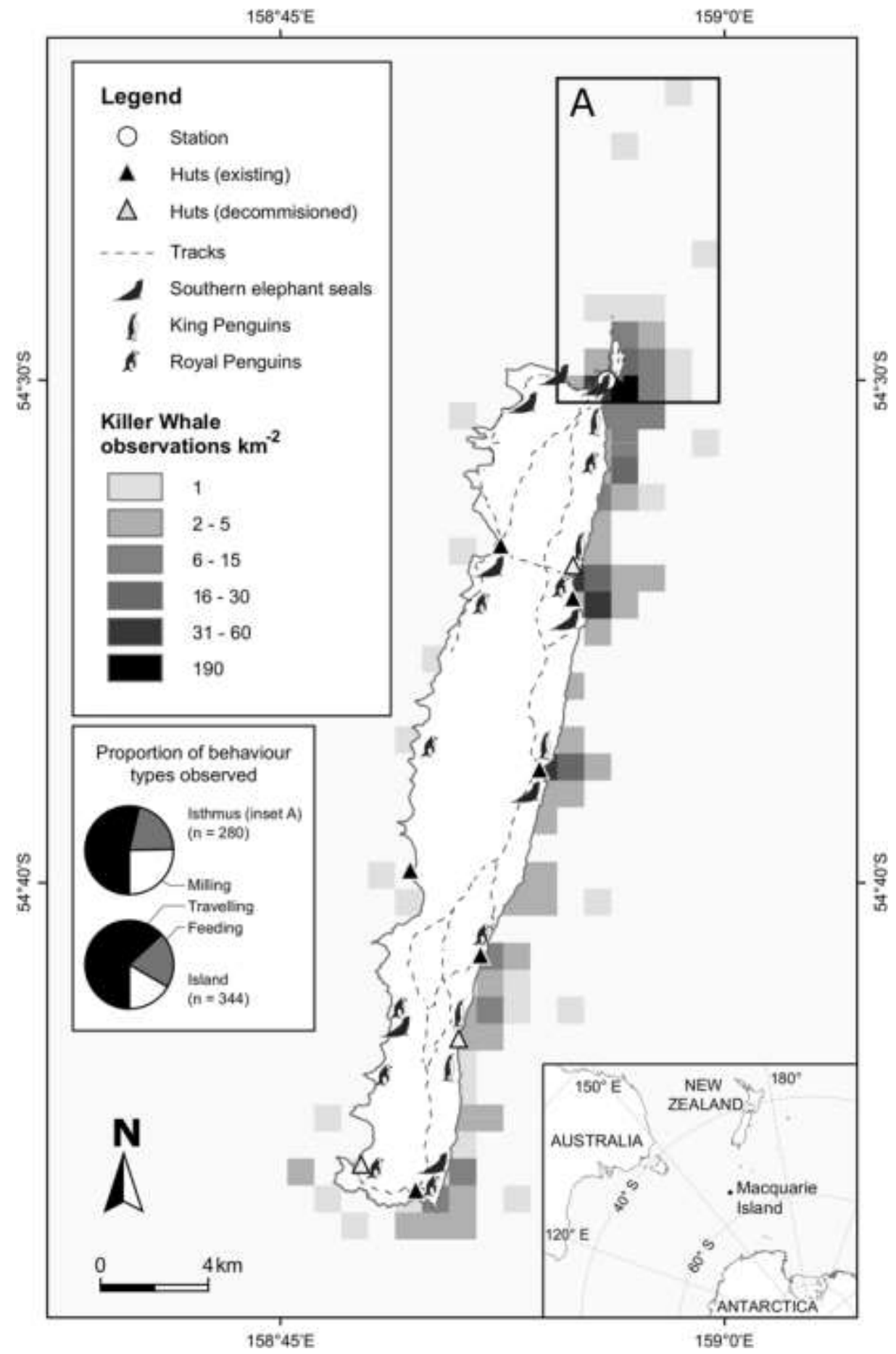

Figure 1. Map of Macquarie Island showing the numbers of killer whale (Orcinus orca) sightings in near-shore waters (1986, 1989-2015). Also shown are the locations of refuges (huts), and the main research station on the islands northern end. Inset lower right shows the location of Macquarie Island between Australia, New Zealand and Antarctica. Box A denotes the extent of the isthmus study area. Left lower inset = pie charts comparing proportions of whale behaviours observed within Box A and the remainder of the island. Note: refuges marked with open triangle were decommissioned following the mid-1990s. Hut names are available from http://data.aad.gov.au/database/mapcat. 


\section{Observational data}

A dataset of shore-based sightings of killer whales was compiled over a 27-year study period from December 1986 until August 2015, excluding 1987 and 1988 when no observations were made. We acknowledge the opportunistic nature of this long-term study likely resulted in a dataset containing potential sampling biases from sources including observation location, weather, day length, visibility, observer experience and variation in observer numbers. While accounting for such observation-related biases was beyond the scope of this study, we note that the results of two similar long-term opportunistic sighting studies of Sub-Antarctic killer whales (Condy et al. 1978; Keith et al. 2001) were confirmed by ecological studies on the same island including a structured observational study designed to minimize such biases, incorporating standardised year-round observation effort (Reisinger et al. 2011a), and a satellite telemetry study (Reisinger et al. 2015). This suggests that the ecological patterns we studied should be accurately represented in our data.

\section{Spatial and temporal occurrences}

Sea-surface positions of killer whales were estimated from records containing observer location, a bearing to the sighting position and an estimate of distance offshore. Estimated positions were plotted as fixed kernel densities within $1 \mathrm{~km}^{2}$ grid cells aligned with UTM projection in ARCMAP 10.3 (Environmental Systems Research Institute, Redlands, CA). Locations of island infrastructure including walking tracks, the research station, field huts, and breeding aggregations of potential prey were overlaid on the kernel density map to visualise factors potentially contributing to concentrations of killer whale sightings.

Seasonal variation in whale occurrence was analysed using sighting probabilities $\left(P_{j}\right.$ with upper (UCL) and lower ( $L C L)$ 95\% confidence limits) calculated for each month $(j)$ across all 
study years using PRESENCE 11.2 (Hines 2006), where $P_{j}=P($ observing a killer whale in month $j \mid$ the killer whale is present at Macquarie Island in month $j$ and can be sighted). The second term of this probability function relies on a whale being able to be sighted, and herein lies a potential bias. Both observer effort (e.g. the location and number of observers on the island across months) and environmental factors (e.g. day length, visibility and weather) varied across months and are a source of bias towards summer months. As such, we restricted the analysis to that of presence/absence in a given month rather than using count data. This approach dampens the effect of increased summer counts on sighting probabilities and meant killer whales only had to be seen once in a month to gain a maximum $P_{j}=1.00$. Sighting probabilities were then visually compared with the phenology of the four primary prey at Macquarie Island; 1) King Penguins, 2) Royal Penguins, 3) adult southern elephant seals, and 4) weaned southern elephant seal pups.

\section{Whale behaviour and predation}

Whale behaviours were initially categorised into three classes, 1) directional travel, 2) milling - describing whales that either showed no consistent directional movement or remained in an area for a prolonged period but not feeding, and 3) feeding - when whales were observed actively pursuing, killing or consuming prey.

To test whether spatial aggregations of potential prey influenced whale behaviour, we compared the proportions of the three behavioural classes recorded for the isthmus subarea (Fig. 1A), a region of relatively high southern elephant seal activity (Carrick et al. 1962), with the remainder of the island. The difference between observed behaviours at the isthmus and the rest of the island were compared statistically using a G-test with the DESCTOOLS package 0.99.17 in R (R Core Team 2015, Signorell 2016). To assess which behavioural 
categories varied between island and isthmus locations, contrast coefficients $\left(C_{i}\right)$ with upper and lower 95\% confidence limits ( $U C L$ and $L C L$, respectively), and $p$ values were calculated for each behaviour class in a binomial generalised linear model (GLM) of location (either isthmus or island) as a function of behavioural classification (feeding, milling and travelling). Contrast coefficients compare the least squares mean for a behaviour class in one level (in this case isthmus) with the average least-squares mean for that behaviour class over both levels, and were calculated using the LSMEANS package 2.26.3 (Lenth 2016) in R (R Core Team 2015).

The diet of killer whales in the near-shore ecosystem was investigated using observed feeding events where prey were identified to family or a lower taxonomic level. Seasonal changes in prey consumption during the study were determined by grouping feeding observations into two periods, October to March covering summer months and April to September covering the winter months. The proportions of total feeding events attributed to each prey type were calculated for each period.

\section{Group size and demographic structure}

Where possible the number of individuals in a group was recorded and whales categorised into sex/age classes according to dorsal fin shape and size, and body size as either: 1) adult male, 2) sub-adult/female and 3) juvenile/calf. Because these are detection-only observations, our analysis included records where at least one age/sex class was positively observed. Where there was no estimate in a given class for a record that contained values in other classes, the value for the given class was set at zero for that sighting and included in the analyses. Seasonal patterns in group structure were investigated using group size and age/sex classes for each yearly quarter (January-March, April-June, July-September, and October- 
December). Median, interquartile range (IQR) and outlier values (beyond $1.5 \times \mathrm{IQR}$ ) were plotted using the GGPLOT package 2.1.0 (Wickham 2009) in R (R Core Team 2015).

To test whether group size varied with whale behaviour, a generalised additive model (GAM) was fitted to the number of observations of killer whales as a function of group size within each behavioural class using the MGCV package 1.8.17 (Wood 2004) and the GGPLOT package 2.1.0 (Wickham 2009) in R (R Core Team 2015). Model fit $\left(R^{2}\right)$ and the significance of smoothed terms (estimated degrees of freedom $\left(e d f_{i}\right)$, Chi-squared $\left(\chi^{2}{ }_{i}\right)$ and $p$-values for group size by behavioural class) were calculated for interpretation of results. For this analysis feeding and milling groups were combined into a single behavioural class (feeding/milling) as these behaviours may be considered closer to one another on a behavioural continuum than to directional travel.

\section{Results}

Spatial and temporal occurrences

Killer whales were sighted along much of Macquarie Island's coastline ( $n=682$ sightings); however, the distribution of sightings was not spatially uniform with fewer whales sighted on the west coast compared to the east coast (Fig. 1). The greatest number of sightings $(n=190)$ occurred within a $1-\mathrm{km}^{2}$ grid cell that included the isthmus study area (Fig. 1A) where the research station is located and over 3000 southern elephant seals congregate annually to breed (van den Hoff et al. 2007). High numbers of killer whale sightings (>6) also occurred along the predominantly leeward east coast in grid cells adjacent field huts, and breeding congregations of seals and penguins (Fig. 1). 
Killer whales were detected year-round at Macquarie Island (Fig. 2). However, observers were three times more likely to detect whales in summer than in winter. May had the lowest sighting probability $\left(P_{j}=0.30, L C L=0.16, U C L=0.49\right)$ and December the highest $\left(P_{j}=\right.$ $0.85, L C L=0.67, U C L=0.94)$.

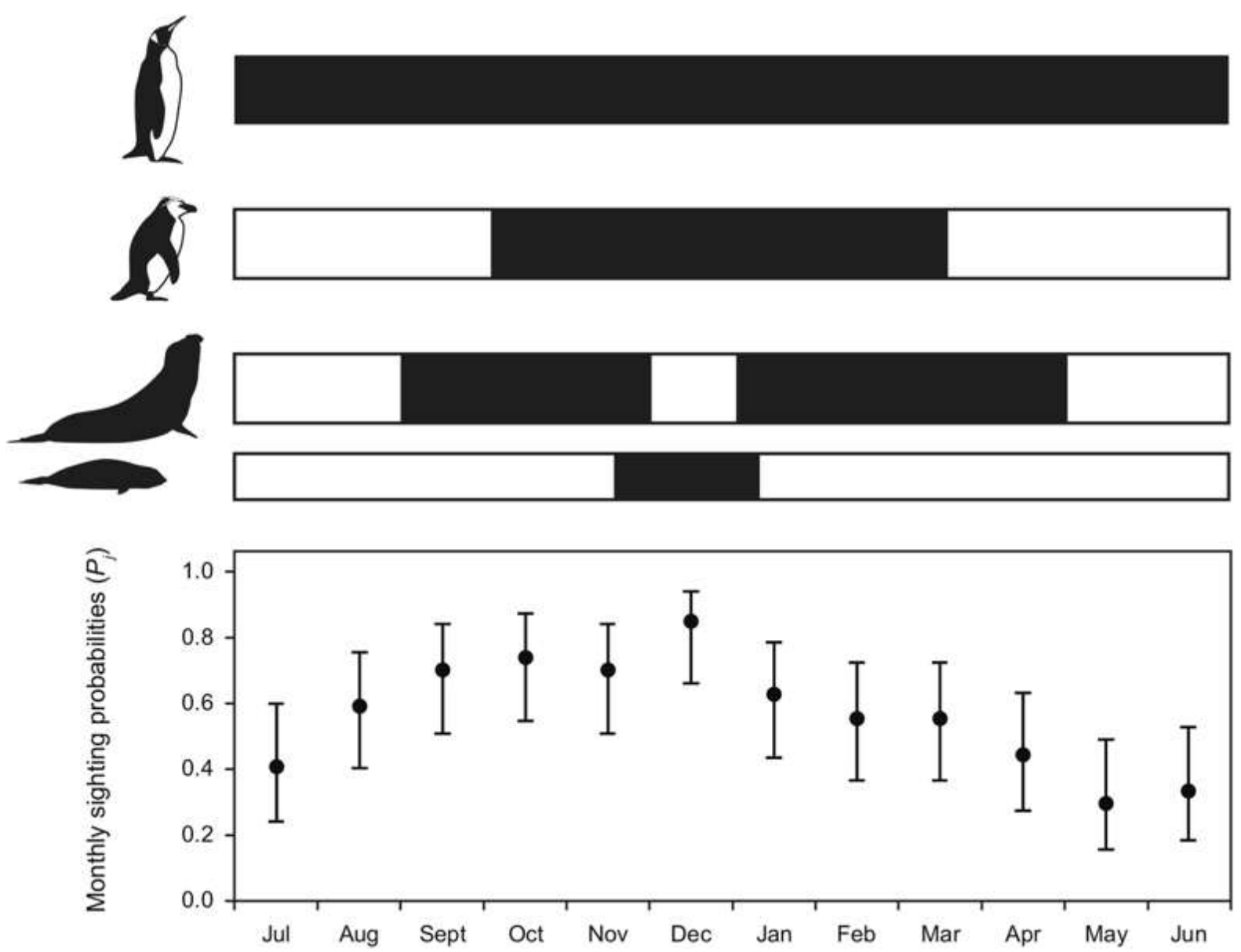

Figure 2. Monthly sighting probabilities ( $\pm 95 \%$ confidence limits) (lower panel) for killer whales (Orcinus orca) at Macquarie Island (1986, 1989-2015). Upper panels show the seasonal availability (presence = black bars) of potential prey. King Penguin Aptenodytes patagonicus (top), Royal Penguins Eudyptes schlegeli (topmiddle), adult southern elephant seal (Mirounga leonina) (bottom-middle) and weaned southern elephant seal pups (bottom). Prey phenologies adapted from Hindell (1988a), Hindell (1988b) and Hindell and Burton (1988).

\section{Whale behaviour and predation}

There was a significant difference in whale behaviours observed within the isthmus subarea ( $n=280$ sightings) vs the remainder of the island $(n=344)\left(G=8.1983, \chi^{2} \mathrm{df}=2, p=\right.$ 
0.0166). Whales were observed spending more time milling at the isthmus $\left(C_{\text {mill }}=0.32, L C L\right.$ $=0.00, U C L=0.65, p=0.027)$ and less time travelling $\left(C_{\text {trav }}=-0.26, L C L=-0.52, U C L=\right.$ $0.00, p=0.027)$ compared with the rest of the island. The proportion of observed feeding events did not differ statistically between study subareas $\left(C_{\text {feed }}=-0.06, L C L=-0.39, U C L=\right.$ 0.26, $p=0.64$, Fig. 1 inset).

Of all feeding events observed $(n=146)$, prey were identified on 75 occasions. Of those, 40 were identified to species level, while 35 were identified to family or genus. Southern elephant seals accounted for $41 \%$ of identified prey, while pinnipeds in general accounted for $79 \%$ of all prey identified (Fig. 3). Among elephant seals, weaned pups were the most frequently observed age class taken, accounting for $65 \%$ of all elephant seal predations. Killer whales also preyed upon King $(n=4)$, Royal $(n=4)$ and Gentoo Penguins (Pygoscelis рариа) $(n=1)$, and fur seals $(n=2)$ (Fig. 3).

The number of observed feeding events peaked during November and December with $47 \%$ of all events and $49 \%$ of all identified prey observed during those months. This peak was coincident with a peak in sighting probabilities, the cessation of the elephant seal breeding season and the dispersal of weaned pups into near-shore waters. Weaned pups made up over a quarter of all prey identified during the summer months (Figs. 2-4).

Prey could not be positively identified on 67 occasions where feeding was observed. The potential to identify prey diminished with increasing distance from shore, to prey remains being too ambiguous to identify in some cases. Due to the small sample sizes, we found no patterns in either the distance prey were taken from shore or prey type taken according to whale age class or sex. 


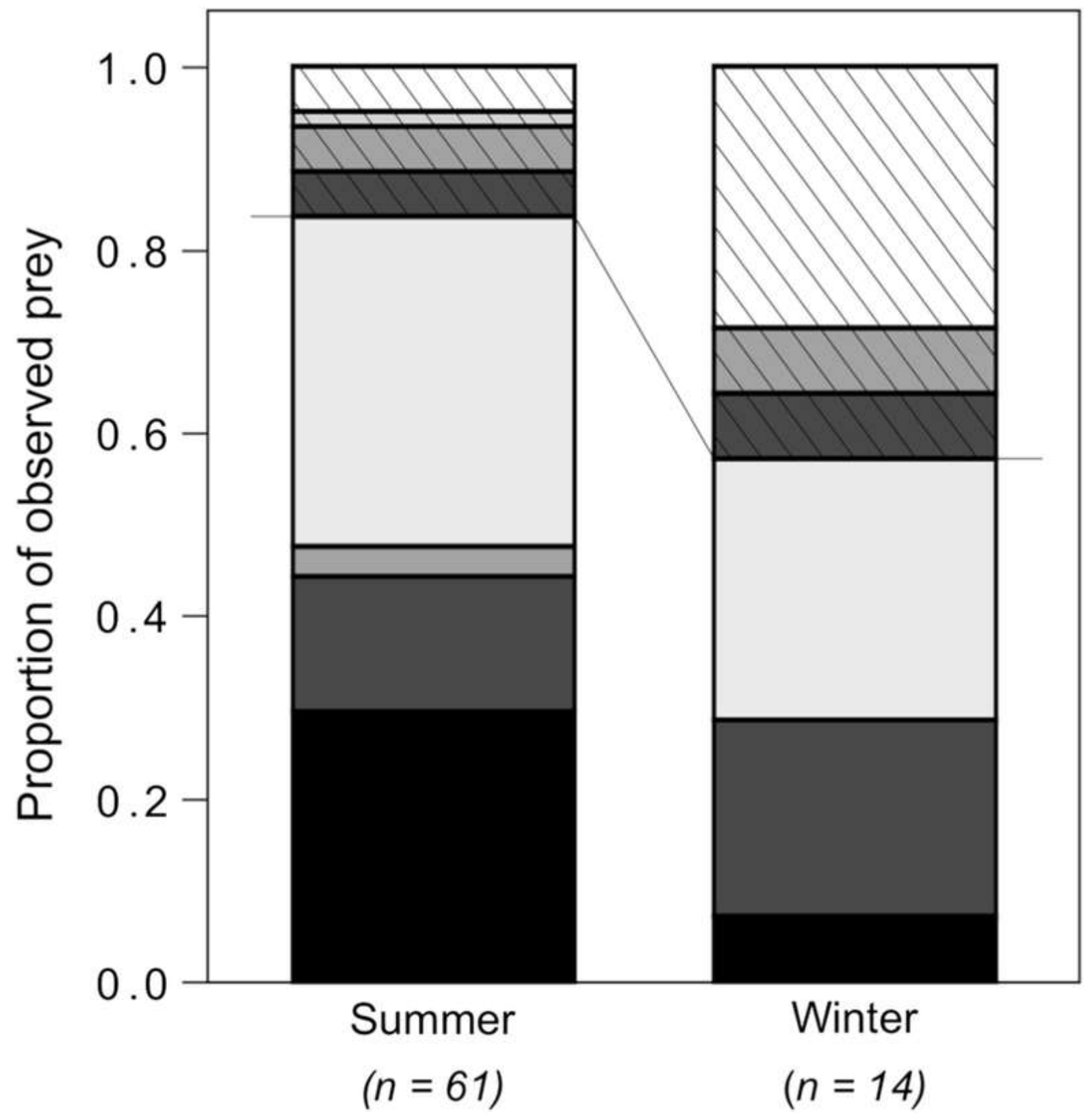

Figure 3. Seasonal changes in the proportions of prey type observed taken by killer whales (Orcinus orca) during summer (October to March; $n=61$ ) and winter (April - September; $n=14$ ) at Macquarie Island (1986, 1989-2015). From bottom to top: solid bar sections: weaned southern elephant seal Mirounga leonina pup; southern elephant seals (other ages); fur seal (spp.); seal (spp.); hatched bar sections: Royal Penguin Eudyptes schlegeli; King Penguin Aptenodytes patagonicus; Gentoo Penguin Pygoselis papua; penguin (spp.). 


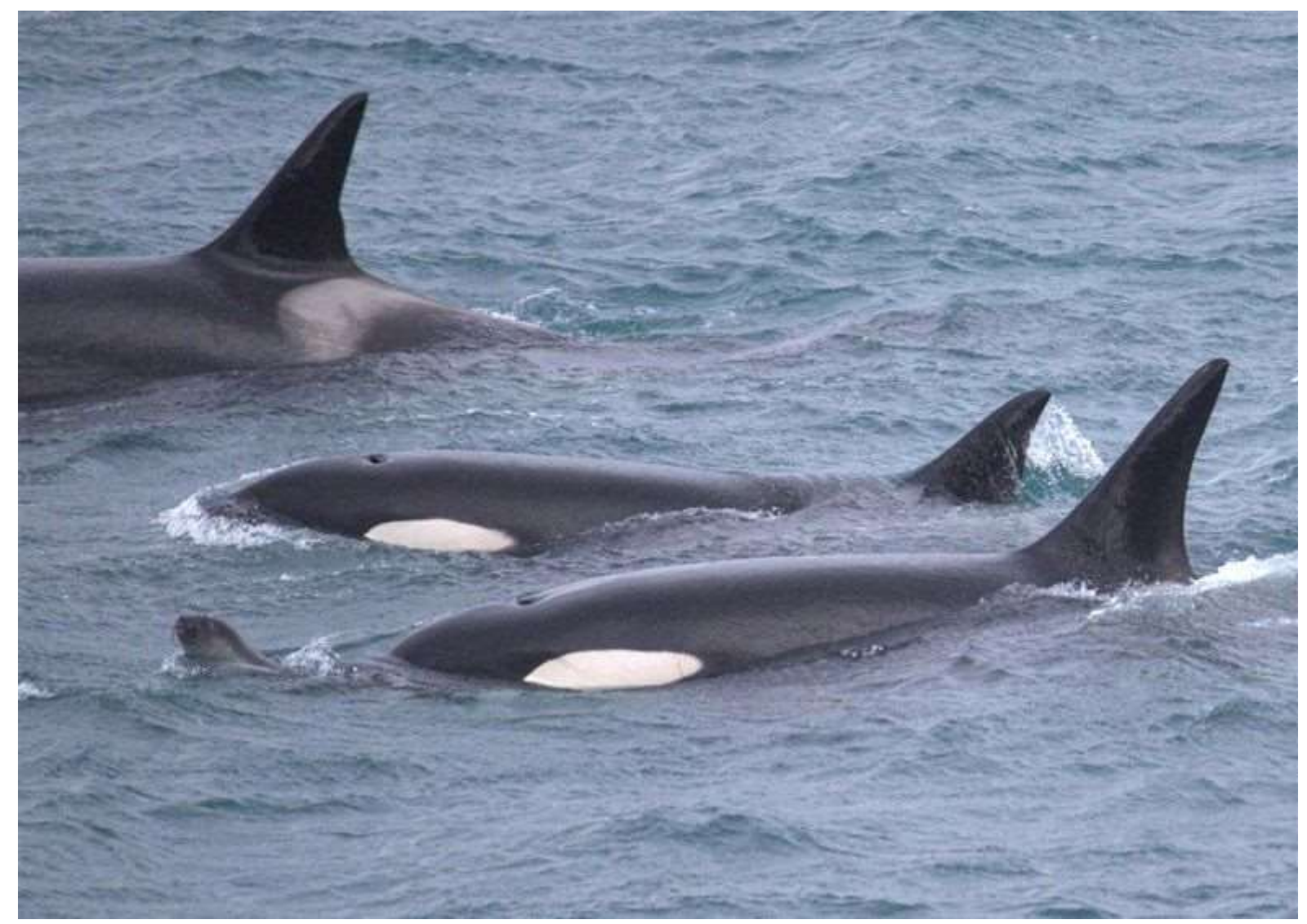

Figure 4. Reincarnation appears to be this young elephant seals' best chance at reproductive success. A group of killer whales (Orcinus orca) have captured their favoured prey, a weaned southern elephant seal (Mirounga leonina) pup, from the near-shore environment at Macquarie Island (06/12/2015), photo courtesy of Lionel Whitehorn.

\section{Group size and demographic structure}

The median group size for killer whales based on all observations $(n=411)$ numbered three individuals (range 1-23, Fig. 5A, Table 1). The largest range in group size was observed during the October to December quarter (median $=3,1.5(I Q R)=1-9$; Fig. 5A) when variance in the number of sub-adult/female per group was highest. The lowest median group sizes were observed in the April to June quarter (median $=2.5,1.5(I Q R)=1-4$; Fig. 5A). 
Table 1. Mean group size and seasonality for pinniped-eating killer whales (Orcinus orca) observed from land at mid to high latitude Southern Hemisphere study sites. Latitude expressed as decimal degrees south. *includes data from Reisinger et al. (2011a). ND = no data

\begin{tabular}{|c|c|c|c|c|}
\hline Study sites & Latitude & $\begin{array}{c}\text { Group size } \\
\text { mean (range) }\end{array}$ & $\begin{array}{c}\text { Peak sightings } \\
\text { (months) }\end{array}$ & Sources \\
\hline Northern Patagonia & 42.00 & $3.7(2-12)$ & Dec, Mar-May & $\begin{array}{l}\text { Lopez and Lopez } 1985, \\
\text { Iñíguez } 2001\end{array}$ \\
\hline Crozet Islands & 46.43 & $4.2(2-7)$ & Oct.-Dec., Mar-Apr & Guinet 1991 \\
\hline Prince Edward Islands & 46.63 & $3.7(1-5)$ & Sept-Oct, Apr-May* & Pistorius et al. 2012 \\
\hline Marion Island & 46.90 & $3(1-13)$ & Sept-Dec, Apr-May & Reisinger at al. 2011a \\
\hline Chilean Patagonia & 53.50 & $4.2(1-15)$ & Dec, Apr-May & $\begin{array}{c}\text { Haussermann et al. 2013, } \\
\text { Capella et al. } 2014\end{array}$ \\
\hline Bird Island & 54.00 & ND & Jan-Apr, Sept & Moore et al. 1999 \\
\hline Macquarie Island & 54.50 & $3(1-23)$ & Oct-Dec & This study \\
\hline
\end{tabular}



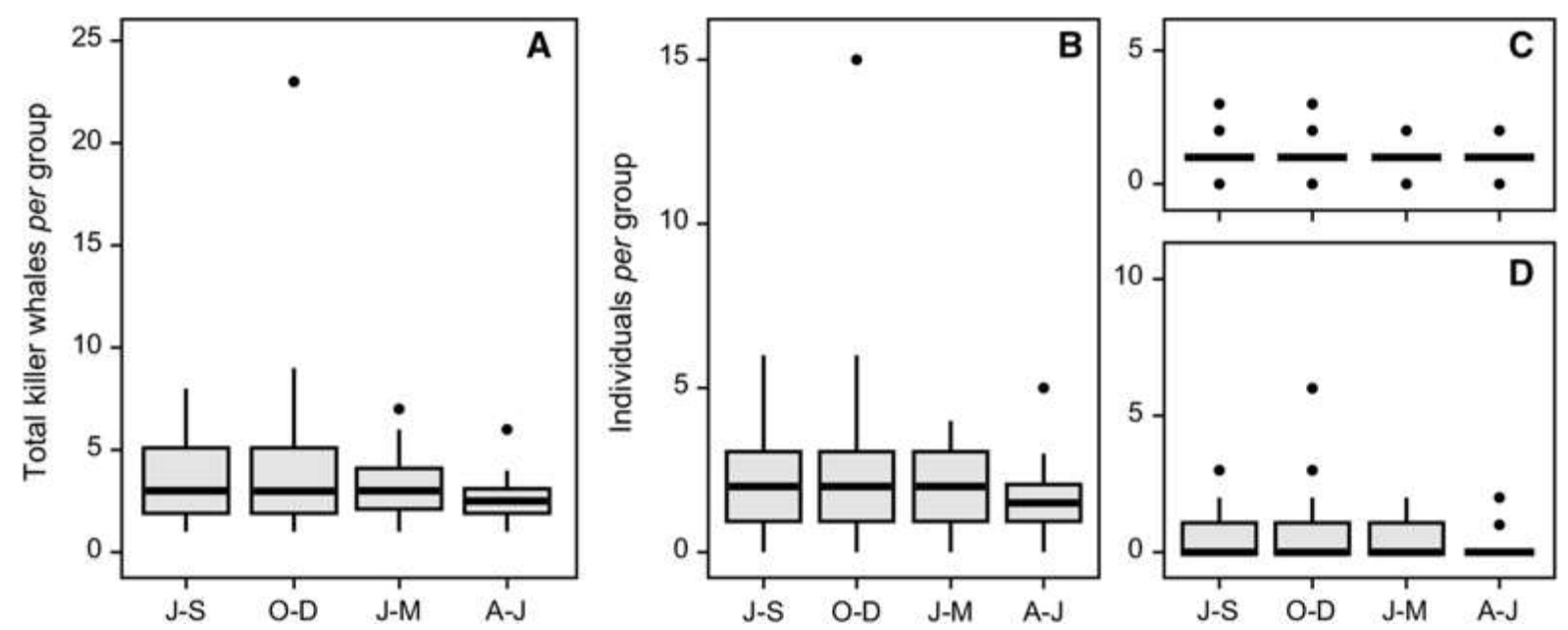

Figure 5. Box and whisker plots showing group size statistics for killer whales (Orcinus orca) observed during each yearly quarter (e.g. July to September, J-S) at Macquarie Island (1986, 1989-2015). Total numbers of killer whales (A), sub-adults and females (B), adult males (C) and calves (D) per group. Hinges extended from the $1^{\text {st }}$ to the $3^{\text {rd }}$ quartile, solid black bars $=$ median values. Whiskers $=1.5 \times$ inter-quartile range $(I Q R)$ from the hinges with dots showing outlier values.

Sub-adult/female whales were the most abundant age/sex class observed; one group contained up to 15 individuals of this class (Fig. 5B). In comparison, the number of adult males per group ranged from none to two, although $75 \%$ of singletons observed were adult males (Fig. 5C). Although variable in number, whales in the juvenile/calf class were seen year-round with a maximum of six seen in a single group during the October-December quarter (Fig. 5D).

Group size varied between the feeding/milling and travelling behaviour classifications $\left(R^{2}=\right.$ $0.834 ; e d f_{\mathrm{f} / \mathrm{m}}=2.61 \chi^{2} \mathrm{f} / \mathrm{m}=44.04 ; e d f_{\mathrm{t}}=2.38 \chi^{2}=102.48$; both behaviours $p>0.001$, Fig. 6). Groups observed feeding/milling had a peak group size of 3 to 5 individuals with a positively skewed distribution. Observations of travelling groups had a negative correlation with group size, singletons being the most common group size observed travelling. 


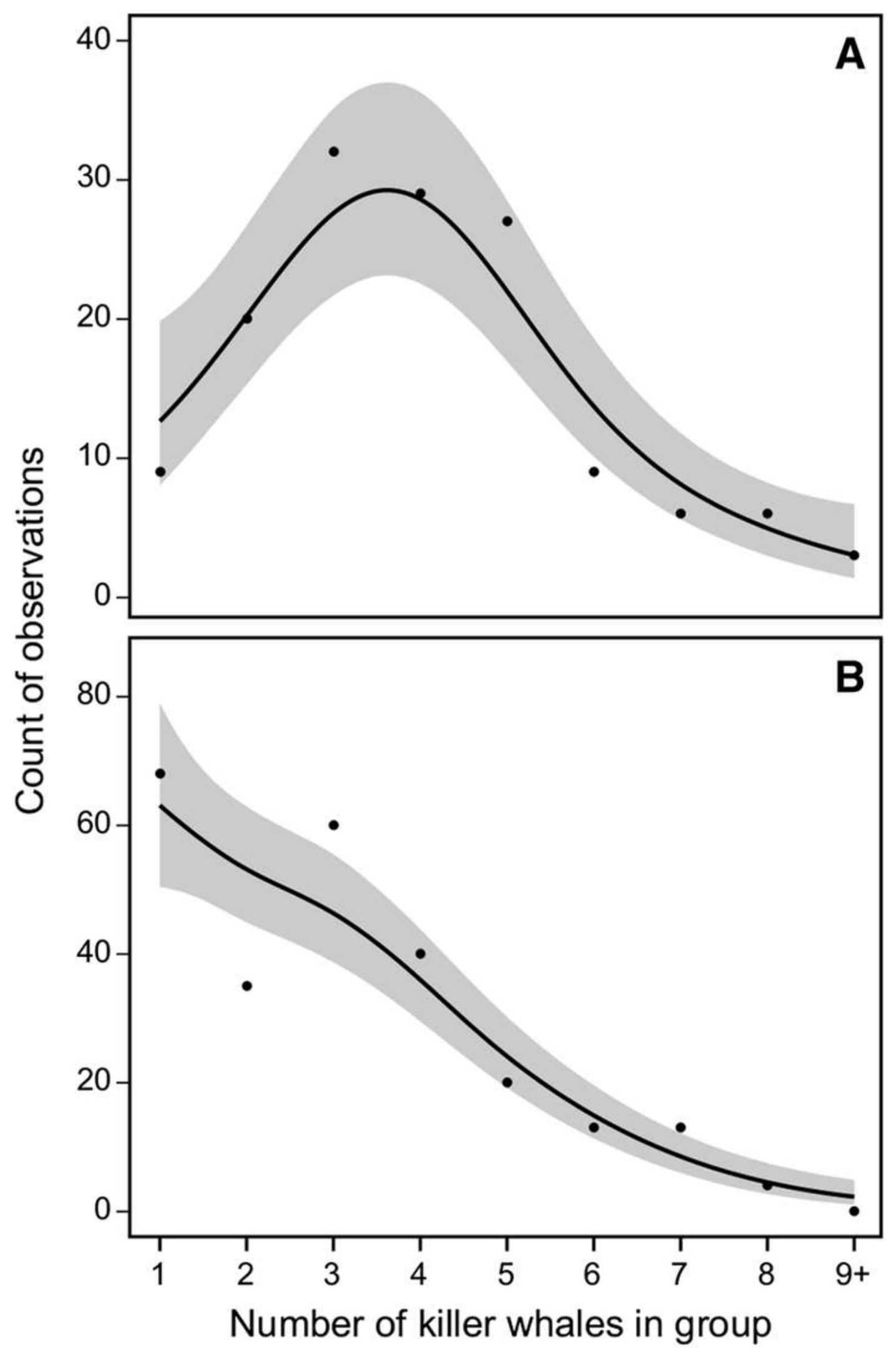

Figure 6. Functional response relationships between group size and the behaviour of killer whales (Orcinus orca) observed at Macquarie Island (1986, 1989-2015). A, feeding/milling $(n=141)$. B, travelling $(n=253)$. Grey area denotes the bounds of the $95 \%$ confidence intervals. 


\section{Discussion}

This study of killer whale seasonality, behaviour diet and group structure suggests that groups observed at Macquarie Island share a similar ecology to those studied at the Crozet Islands and the Prince Edward Islands. At Sub-Antarctic locations, killer whales are mainly seen during the Austral summer in small groups of one to five individuals preying upon pinnipeds and, to a lesser extent, penguins. This long-term study provides evidence of a relatively stable seasonality of occurrence and group structure. A pattern of monthly fluctuations in sightings in the near-shore environment was coincident with the seasonal availability of prey, especially southern elephant seals.

\section{Seasonality and local distribution}

The seasonal pattern in killer whale sightings at Macquarie Island (Fig. 2) shared similarities with patterns at other mid to high latitude SH study sites (Table 1), however there was no clear bimodality in whale presence like that observed at the Crozet Islands (Guinet 1991) and Marion Island (Reisinger et al. 2011b). Nevertheless, there was a general pattern emerging of low whale sightings in the Sub-Antarctic during winter (June-August) rising to peak through early to mid-summer (September-December). Across both the Northern and the SH, seasonality in the occurrence of killer whales in near-shore waters has been positively linked to seasonality in local prey availability (Fig. 2 this study; Reisinger et al. 2011b; Higdon et al. 2012).

Like other Sub-Antarctic islands, the probability of detecting killer whales at Macquarie Island peaked during the terrestrial breeding phase of the southern elephant seal - the most frequently identified prey of killer whales in the near-shore environment at Sub-Antarctic islands (Fig. 2 this study; Condy et al. 1978; Iñíguez 2001; Reisinger et al. 2011b). Sighting 
probabilities increased in spring when well-nourished adult elephant seals began concentrating at the island to breed and decreased with their dispersal to sea following the cessation of the adult moult haulout in autumn (Hindell and Burton 1988). Notably, sighting probabilities were highest in December (Fig. 2) when weaned pups entered the shallow nearshore waters prior to dispersing into the greater Southern Ocean (McConnell et al. 2002).

Killer whales are known to exert top-down pressure on pinniped populations (Reisinger et al. 2011c; Baylis et al. 2015; Maniscalco et al. 2015). The southern elephant seal population at Macquarie Island has experienced significant reductions in abundance over time, and killer whale predation has been proposed as one possible driver of these changes (McMahon et al. 2005). This study shows that killer whales do exert a top-down influence on the mortality of juvenile and adult elephant seals, however this study cannot the degree of influence. In addition, the question of whether killer whale abundance or annual take of elephant seals has changed at Macquarie Island over time cannot be deduced from our data.

The apparent specialisation of killer whales on elephant seals over the summer months suggests local fluctuations in prey numbers could exert bottom-up influences on killer whales (Ford et al. 2010). For example, a severe reduction in the availability of weaned elephant seal pups could result in killer whale group-responses including increased competition for prey, prey switching, or groups seeking alternative foraging grounds as has been suggested for killer whales and observed in other apex predators (Estes et al. 1998; Estes et al. 2009; Ritchie and Johnson 2009; Pitman et al. 2015).

The spatial distribution of killer whales around Macquarie Island also reflects patterns observed at other Sub-Antarctic islands. Killer whales were most commonly sighted adjacent 
the isthmus research station and field hut locations on the, predominantly leeward, east coast of Macquarie Island (Fig. 1 main map). The very similar distributional pattern reported for Marion Island was attributed not only to variability in search effort confounded by field hut locations, but also to the clumped distribution of prey around the island (Keith et al. 2001).

Infrastructure location may have contributed to the observed distribution at Macquarie Island, however we believe such potential sources of sighting biases do not detract from the findings and interpretation of the data collected for this study, for two reasons. First, as previously mentioned, a structured year-round sightings study of killer whales at Marion Island (Reisinger et al. 2011a) confirmed the conclusions from two previous opportunistic, longterm studies undertaken at the same island (Condy et al. 1978; Keith et al. 2001). Second, many of Macquarie Islands' coastal field huts have been located at sites historically established to exploit, and later to study, breeding aggregations of elephant seals, fur seals and penguins, all of which contributed proportionally to the diet of the whales at the island (Fig. 3). Given the relationship between killer whale sighting probability and seasonal prey availability (Fig. 2), it seems reasonable to suggest the whales' spatial distribution was influenced by the distribution of their prey, as has been reported for killer whales at Marion Island (Keith et al. 2001, Reisinger et al. 2011b).

\section{Diet and behaviour}

Diet was another aspect of the whale's ecology that shared a degree of commonality with populations studied at other Sub-Antarctic islands. Surface feeding events revealed pinnipeds contributed regularly to the whales' diet compared to other available prey species (Fig. 3). Weaned pups was the most frequent elephant seal age class taken at Macquarie Island (Figs. 3, 4), and also at Crozet Islands (Guinet 1992). At Macquarie Island over half of all observed 
killer whale attacks on elephant seals took place within $100 \mathrm{~m}$ of shore and weaned pups were routinely taken in sheltered embayments, such as Garden Cove on the island's isthmus, where they were hunting along the edge of giant kelp (Durvillaea antarctica) beds (Morrice 2004). Our results suggest a prey-driven peak in killer whale sightings at Macquarie Island during summer, when whales exploit the dispersal of numerous, fat, naïve weaned elephant seal pups into the islands near-shore waters.

Adult southern elephant seals were also hunted at Macquarie Island as they were at Marion Island (Reisinger et al. 2011a) and the Crozet Islands (Guinet 1992). Adult elephant seals are proficient deep divers that, evident from bite wounds left on the seals (van den Hoff and Morrice 2008), have the capacity to survive killer whale attacks. The capture of adult seals in the inshore environment during summer is likely made easier because their numbers are seasonally high, and their escape capacity would be constrained by a shallowing bathymetry.

In this study, prey could not be identified in $49 \%$ of all observed feeding events. Factors contributing to this included distance from shore, underwater feeding, feeding on small prey (e.g. penguins), and poor visibility due to low light levels, glare and inclement weather. The relatively small body size of the penguins means their observed contribution to the whales' diet may be under-represented in this study. Whether individual whales or specific groups specialised on particular prey types remains equivocal because feeding events were not linked to individual identity or groups.

Compared to the sightings around the island more generally, killer whales spent less time travelling and more time milling within the isthmus subarea, suggesting the whales were searching for prey or resting in this area. The difference between the study locations is likely 
due to the locally high concentration of southern elephant seals breeding on the isthmus compared to the rest of the island. Carrick et al. (1962) previously noted the activities of adult and weaned elephant seals at the isthmus may make it an attractive hunting ground for killer whales.

\section{Group size}

Group size at Macquarie Island ranged from singletons to 23 whales; the most common group size was three individuals. Group size in killer whales has been examined in terms of prey preference, prey size and maximising energy intake per kill (Jefferson et al. 1991; Baird and Dill 1996). Globally, there is a degree of congruence between group size and broad prey type with fish-eating killer whales usually having larger group sizes than those feeding on marine mammals. In the coastal waters of the eastern North Pacific, for example, mammaleating killer whales are found in groups of 2-6 individuals, while fish-eating groups had a mean pod size of 18 (Ford and Ellis 2014). Similarly, killer whales that appeared to feed mainly on fish in the Antarctic had an average group size of 46 individuals, while two mammal-eating types, one which was assumed to feed on pinnipeds, the other on Antarctic minke whales (Balaenoptera bonaerensis), had average group sizes of 12 and 14 individuals, respectively (Pitman and Ensor 2003). In the Arctic, average group sizes ranged from pairs hunting pinnipeds, to an average of four for groups hunting bowhead whales (Balaena mysticetus), seven when hunting belugas (Delphinapterus leucas) and narwhals (Monodon monoceros) and eleven when hunting multiple prey (Higdon et al. 2012). Our results fit the widely observed relationship between small group size (3-5 individuals, Table 1) and pinniped predation and are similar to the average group size of killer whales observed at other Sub-Antarctic islands (Table 1). 
Groups of killer whales have been observed to the south of Macquarie Island feeding on Antarctic minke whales (Pitman and Ensor 2003) but killer whales were not observed hunting, attacking or feeding on whales near Macquarie Island during this study. This is despite a temporal overlap with known occurrences of pilot whales (Globicephala spp.), humpback whales (Megaptera novaeangliae) and minke whales migrating near to the island (Clarke et al. 2017). The larger groups of killer whales observed at Macquarie Island may therefore be temporary associations of smaller, stable social groups, as at Marion Island (Reisinger et al. 2017) and in the Eastern North Pacific Ocean (Baird and Dill 1995; Baird and Dill 1996; Baird and Whitehead 2000). Further research is needed to test whether this is the case, and if so, whether such amalgamations are for cooperative foraging or for social reasons (Baird and Dill 1996; Reisinger et al. 2017).

\section{Future work}

The analyses of several decades of data collection has contributed an understanding of the ecology of an apex-predator, the killer whale, operating within the near-shore environment at Sub-Antarctic Macquarie Island. The study site lies geographically central to the Ross Sea, Australia and New Zealand where killer whales have also been observed yet nothing is known of their broader migratory movements and population connectivity. Where the whales go and what their diet consists of after leaving Macquarie Island may have broad conservation and management implications, especially in relation to the whale's potential for dietary overlap with local and distant commercial fisheries operations (Guinet et al. 2015) and fluctuating prey populations.

Moreover, nothing is known of the strength of the top-down and bottom-up relationships between killer whale and their prey populations at Macquarie Island. The common and 
relatively stable ecological characteristics that the whales share with other Sub-Antarctic populations suggests it will be important to improve our understanding of the whale's dietary and behavioural plasticity to better predict how they might respond to longer-term changes in local prey availability expected from environmental change.

\section{Acknowledgements}

Many thanks go to those keen-eyed expeditioners who contributed sightings data for killer whales at Macquarie Island. Shannon McKay, Catherine Bell, Marguerite Tarzia and Maria Garcia assisted with the database maintenance. The Whale and Dolphin Conservation Society are thanked for their support in an early collation of data for a Technical Report by MM.

\section{Conflicts of Interest}

The authors declare no conflicts of interest.

\section{Authors' contributions}

TT, contributed to data analyses and the writing of the paper, JvdH, conceived the research, collected data, contributed to data analyses and the writing of the paper, coordinated author input, $\mathrm{KC}$, collected data, contributed to data analyses and the writing of the paper, RR, contributed to the writing of the paper, PJNdB contributed to writing the paper, M-AL, collected data, contributed to data analyses and the writing of the paper, MM, conceived the research, collected data, contributed to data analyses and the writing of the paper, coordinated author input 


\section{References}

Ainley DG, Ballard G (2012) Trophic Interactions and Population Trends of Killer Whales (Orcinus orca) in the Southern Ross Sea. Aquat Mamm 38:153-160

Baird RW, Dill LM (1995) Occurrence and behaviour of transient killer whales: seasonal and pod-specific variability, foraging behaviour, and prey handling. Can J Zool 73:1300-1311. https://doi.org/10.1139/z95-154

Baird RW, Dill LM (1996) Ecological and social determinants of group size in transient killer whales. Behav Ecol 7:408-416. https://doi.org/10.1093/beheco/7.4.408

Baird RW, Whitehead H (2000) Social organization of mammal-eating killer whales: group stability and dispersal patterns. Can Zool 78:2096-2105. https://doi.org/10.1139/z00-155

Baylis AMM, Orben RA, Arnould JPY, Christiansen F, Hays GC, Staniland IJ (2015)

Disentangling the cause of a catastrophic population decline in a large marine mammal. Ecology 96:2834-2847. https://doi.org/10.1890/14-1948.1

Bergstrom DM, Chown SL (1999) Life at the front: history, ecology and change on southern ocean islands. Trends Ecol Evol 14:472-477. https://doi.org/10.1016/S0169-5347(99)01688-2

Capella JJ, Abramson JZ, Vilina YA, Gibbons J (2014) Observations of killer whales (Orcinus orca) in the fjords of Chilean Patagonia. Polar Biol 37:1533-1539

Carrick R, Csordas SE, Ingham SE, Keith K (1962) Studies on the southern elephant seal, Mirounga leonina (L.). III. The annual cycle in relation to age and sex. CSIRO Wildl Res 7:119-160. https://doi.org/10.1071/CWR9620119

Chambers LE et al. (2013) Phenological Changes in the Southern Hemisphere. PLOS ONE 8:e75514. https://doi.org/10.1371/journal.pone.0075514

Clarke RH, Gales R, Schulz M (2017) Land-based observations of cetaceans and a review of recent strandings at subantarctic Macquarie Island. Aust Mammal 39:248-253. https://doi.org/10.1071/AM16007 
Clausius E, McMahon CR, Hindell MA (2017) Five decades on: Use of historical weaning size data reveals that a decrease in maternal foraging success underpins the long-term decline in population of southern elephant seals (Mirounga leonina). PLOS ONE 12:e0173427. https://doi.org/10.1371/journal.pone.0173427

Condy PR, Van Aarde RJ, Bester MN (1978) The seasonal occurrence and behaviour of Killer whales Orcinus orca, at Marion Island. J Zool 184:449-464. https://doi.org/10.1111/j.14697998.1978.tb03301.x

de Bruyn PJN, Tosh CA, Terauds A (2013) Killer whale ecotypes: is there a global model? Biol Rev 88:62-80. https://doi.org/10.1111/j.1469-185X.2012.00239.x

Estes JA, Doak DF, Springer AM, Williams TM (2009) Causes and consequences of marine mammal Population declines in southwest Alaska: A food-web perspective. Philos Trans $\mathrm{R}$ Soc B 364:1647-1658. https://doi.org/10.1098/rstb.2008.0231

Estes JA, Tinker MT, Williams TM, Doak DF (1998) Killer Whale Predation on Sea Otters Linking Oceanic and Nearshore Ecosystems. Science 282:473-476. https://doi.org/10.1126/science.282.5388.473

Ford JKB, Ellis GM (2014) You Are What You Eat: Foraging Specializations and Their Influence on the Social Organization and Behavior of Killer Whales. In: Yamagiwa J, Karczmarski L (eds) Primates and Cetaceans: Field Research and Conservation of Complex Mammalian Societies. Springer Japan, Tokyo, pp 75-98. https://doi.org/10.1007/978-4-431$54523-1 \_4$

Ford JKB, Ellis GM, Olesiuk PF, Balcomb KC (2010) Linking killer whale survival and prey abundance: food limitation in the oceans' apex predator? Biol Lett 6:139-142. https://doi.org/10.1098/rsbl.2009.0468

Guinet C (1991) L'orque (Orcinus orca) autour de l'Archipel Crozet comparaison avec d'autres localités. Rev Ecol-Terre Vie 46:321-337. 
Guinet C (1992) Comportement de chasse des orques (Orcinus orca) autour des iles Crozet. Can J Zool 70:1656-1667

Guinet C, Tixier P, Gasco N, Duhamel G (2015) Long-term studies of Crozet Island killer whales are fundamental to understanding the economic and demographic consequences of their depredation behaviour on the Patagonian toothfish fishery. ICES J Mar Sci 72:1587-1597. https://doi.org/10.1093/icesjms/fsu221

Häussermann V, Acevedo J, Försterra G, Bailey M, Aguayo-Lobo A (2013) Killer whales in Chilean Patagonia: additional sightings, behavioural observations, and individual identifications. Rev Biol Mar Oceanog 48:73-85

Higdon JW, Hauser DDW, Ferguson SH (2012) Killer whales (Orcinus orca) in the Canadian Arctic: Distribution, prey items, group sizes, and seasonality. Mar Mamm Sci 28:E93-E109. https://doi.org/10.1111/j.1748-7692.2011.00489.x

Hindell MA (1988a) The diet of the King Penguin Aptenodytes patagonicus at Macquarie Island. Ibis 130:193-203. https://doi.org/10.1111/j.1474-919X.1988.tb00970.x

Hindell MA (1988b) The Diet of the Royal Penguin Eudyptes schlegeli at Macquarie Island. Emu 88:219-226. https://doi.org/10.1071/MU9880219

Hindell MA, Burton HR (1988) Seasonal Haul-Out Patterns of the Southern Elephant Seal (Mirounga leonina L.), at Macquarie Island. J Mammal 69:81-88. https://doi.org/10.2307/1381750

Hines JE (2006) PRESENCE- Software to estimate patch occupancy and related parameters. USGS-PWRC

Iñíguez MA (2001) Seasonal distribution of killer whales (Orcinus orca) in Northern Patagonia, Argentina. Aquat Mamm 27:154-161

Jefferson TA, Stacey PJ, Baird RW (1991) A review of Killer Whale interactions with other marine mammals: predation to co-existence. Mamm Rev 21:151-180. https://doi.org/10.1111/j.1365-2907.1991.tb00291.x 
Keith M, Bester MN, Bartlett PA, Baker D (2001) Killer whales (Orcinus orca) at Marion Island, Southern Ocean. Afr Zool 36:163-175. https://doi.org/10.1080/15627020.2001.11657134

Kenny R, Haysom N (1962) Ecology of rocky shore organisms at Macquarie Island. Pac Sci $16: 245-263$

Lenth RV (2016) Least-Squares Means: The R Package lsmeans. J Stat Softw 69:33. https://doi.org/10.18637/jss.v069.i01

Lopez JC, Lopez D (1985) Killer whales (Orcinus orca) of Patagonia, and their behavior of intentional stranding while hunting nearshore. J Mammal 66:181-183

Maniscalco JM, Springer AM, Adkison MD, Parker P (2015) Population Trend and Elasticities of Vital Rates for Steller Sea Lions (Eumetopias jubatus) in the Eastern Gulf of Alaska: A New Life-History Table Analysis. PLOS ONE 10:e0140982. https://doi.org/10.1371/journal.pone.0140982

McConnell B, Fedak M, Burton HR, Engelhard GH, Reijnders PJH (2002) Movements and foraging areas of naïve, recently weaned southern elephant seal pups. J Anim Ecol 71:65-78. https://doi.org/10.1046/j.0021-8790.2001.00576.x

McMahon CR, Bester MN, Burton HR, Hindell MA, Bradshaw CJA (2005) Population status, trends and a re-examination of the hypotheses explaining the recent declines of the southern elephant seal Mirounga leonina. Mamm Rev 35:82-100. https://doi.org/10.1111/j.13652907.2005.00055.x

Moore MJ, Berrow SD, Jensen BA, Carr P, Sears R, Rowntree VJ. Payne R, Hamilton, PK (1999) Relative abundance of large whales around South Georgia (1979-1998). Mar Mamm Sci 15:1287-1302

Morrice MG (2004) Killer whales (Orcinus orca) in Australian territorial waters. Technical Paper Deakin University, Victoria Australia 
Pistorius PA, Meÿer MA, Reisinger RR, Kirkman SP (2012) Killer whale predation on subantarctic fur seals at Prince Edward Island, Southern Indian Ocean. Polar Biol 35, 1767 1772

Pitman RL, Ensor P (2003) Three forms of killer whales (Orcinus orca) in Antarctic waters. J Cetac Res Manage 5:131-140

Pitman RL, Totterdell JA, Fearnbach H, Ballance LT, Durban JW, Kemps H (2015) Whale killers: Prevalence and ecological implications of killer whale predation on humpback whale calves off Western Australia. Mar Mamm Sci 31:629-657. https://doi.org/10.1111/mms.12182

Poncelet E, Barbraud C, Guinet C (2010) Population dynamics of killer whales in Crozet Archipelago, southern Indian Ocean: exploiting opportunistic and protocol-based photographs in a mark-recapture study. J Cetac Res Manage 11:41-48

R Core Team (2015) R: A language and environment for statistical computing. R Foundation for Statistical Computing, Vienna, Austria

Reisinger RR, Beukes C, Hoelzel AR, de Bruyn PJN (2017) Kinship and association in a highly social apex predator population, killer whales at Marion Island. Behav Ecol 28:750-759. https://doi.org/10.1093/beheco/arx034

Reisinger RR, de Bruyn PJN, Bester MN (2011a) Abundance estimates of killer whales at subantarctic Marion Island. Aquat Biol 12:177-185

Reisinger RR, de Bruyn PJN, Bester MN (2011b) Predatory impact of killer whales on pinniped and penguin populations at the Subantarctic Prince Edward Islands: fact and fiction. J Zool 285:1-10

Reisinger RR, de Bruyn PJN, Tosh CA, Oosthuizen WC, Mufanadzo NT, Bester MN (2011c) Prey and seasonal abundance of killer whales at sub-Antarctic Marion Island. Afr Mar Sci 33:99-105. https://doi.org/10.2989/1814232X.2011.572356 
Reisinger RR, Keith M, Andrews RD, de Bruyn PJN (2015) Movement and diving of killer whales (Orcinus orca) at a Southern Ocean archipelago. J Exp Mar Biol Ecol 473:90-102. https://doi.org/10.1016/j.jembe.2015.08.008

Ritchie EG, Johnson CN (2009) Predator interactions, mesopredator release and biodiversity conservation. Ecol Lett 12:982-998. https://doi.org/10.1111/j.1461-0248.2009.01347.x

Signorell A (2016) DescTools: Tools for descriptive statistics. R package version 0.99.17

Smith VR, Lewis-Smith RI (1987) The biota and conservation status of sub-Antarctic islands. Environ Int 13:95-104. https://doi.org/10.1016/0160-4120(87)90047-X

van den Hoff J, Burton H, Raymond B (2007) The population trend of southern elephant seals (Mirounga leonina L.) at Macquarie Island (1952-2004). Polar Biol 30:1275-1283. https://doi.org/10.1007/s00300-007-0288-9

van den Hoff J, McMahon CR, Simpkins GR, Hindell MA, Alderman R, Burton HR (2014) Bottom-up regulation of a pole-ward migratory predator population. Proc R Soc B 281:20132842. https://doi.org/10.1098/rspb.2013.2842

van den Hoff J, Morrice MG (2008) Sleeper shark (Somniosus antarcticus) and other bite wounds observed on southern elephant seals (Mirounga leonina) at Macquarie Island. Mar Mamm Sci 24:239-247. https://doi.org/10.1111/j.1748-7692.2007.00181.x

Wickham H (2009) ggplot2: Elegant Graphics for Data Analysis. Springer-Verlag, New York Wood SN (2004) Stable and Efficient Multiple Smoothing Parameter Estimation for Generalized Additive Models. J Am Statl Assoc 99:673-686. https://doi.org/10.1198/016214504000000980 